\title{
sciendo
}

\section{Strategies and perspectives reffered to the analysis and development of the preuniversity education system from Romania}

\author{
Lavinia-Ștefania ȚOȚAN \\ The Bucharest University of Economic Studies, Bucharest, Romania \\ laviniatotan@yahoo.com \\ Corina FRĂSINEANU \\ The Bucharest University of Economic Studies, Bucharest, Romania \\ frasineanuc@yahoo.com
}

\begin{abstract}
The paper presents the actual state of the preuniversity education system from Romania, provided, also, solutions and strategies for its development. It describes also the evolution of the preuniversity education system between 2000 and 2018 and also the impact of the european funds in increase of quality for the preuniversity education system. There are realised also prognosis for indicators between 2020 and 2022.
\end{abstract}

Keywords: education, analysis, prognosis, strategy.

\section{Introduction}

From our point of view, the school units are restricted in their mission to help the children in the community and they are not involved at all in the education of adults, as if we did not live in a historical period in which lifelong learning makes a difference. The activity of the school is limited to the class hours, and the children, between the last class hour and the parents' arrival at home, are left at the street corner. The school does not stimulate the active participation in the life of the community and the social responsibility, which can be developed by the involvement in community programs, social assistance activities, support groups, environmental protection etc. The paper analyzes the evolution of the number of teachers according to the enrolled population from preuniversity education system and the number of schools.

\section{Literature review}

In an era of rapid technological change, information exchange and the emergence of knowledge-intensive industries, it is difficult to identify the future demands of the labor market (Smith, 2001).

Unemployment growth in European Union member states and developing countries in Eastern Europe combined with technological changes may result in continuous change in labor market demands, given that the education supply must be in line with the jobs required on the labor market (Noguera, 2004).

Member States of the European Union have researched several methods of employment 
forecasting to identify future workforce needs that take into account sectoral, occupational, educational and training factors that influence job demand and supply (Hughes, 1991).

Some Eastern European countries are interested in developing such models in order to provide the paid labor market with the appropriate training required. Taking into account the demands of the Single Labor Market and increasing international mobility, states must develop models that can be compared with the forecasting methods for training and qualification with those existing in EU Member States (Visco. 2001). This objective involves regular medium-term forecasts that will be extended over time by decision makers, which can be applied throughout the national economy, taking into account factors such as: future investments in the economy, revenue forecasts and labor productivity and, of course, technological exchanges. The development of such forecasts will require the use of quantitative and qualitative methods that will systematically organize and integrate data and analyzes regarding education and vocational training, as well as sectoral and occupational needs. The Netherlands and France are two European countries with extensive experience in the field of occupational and educational forecasts, Ireland being the most recent country. France has the longest tradition in predicting occupational and educational needs, followed by the Netherlands and Ireland, which have recently developed expertise in this area.

\section{Methodology}

We tried to identify a relationship between number of pupils, number of teachers and number of schools. We applied a multiple regression model and we tested some hypotheses above the model. We used Eviews for analyze the data.

The analysis of educational system plays an important part of the development of the country.

The analysis of the main indicators referred to the pre-university educational system are presented in the following figures.

From figure 1 we can conclude that in Romania the evolution of the enrolled population registered a decreasing trend. In 1990/1991 the number of enrolled population was 5.066.031 persons and in 2016/2017 was 3.578 .561 persons.

The average of enrolled population between 1990-2016 was 4.347 .495 persons.

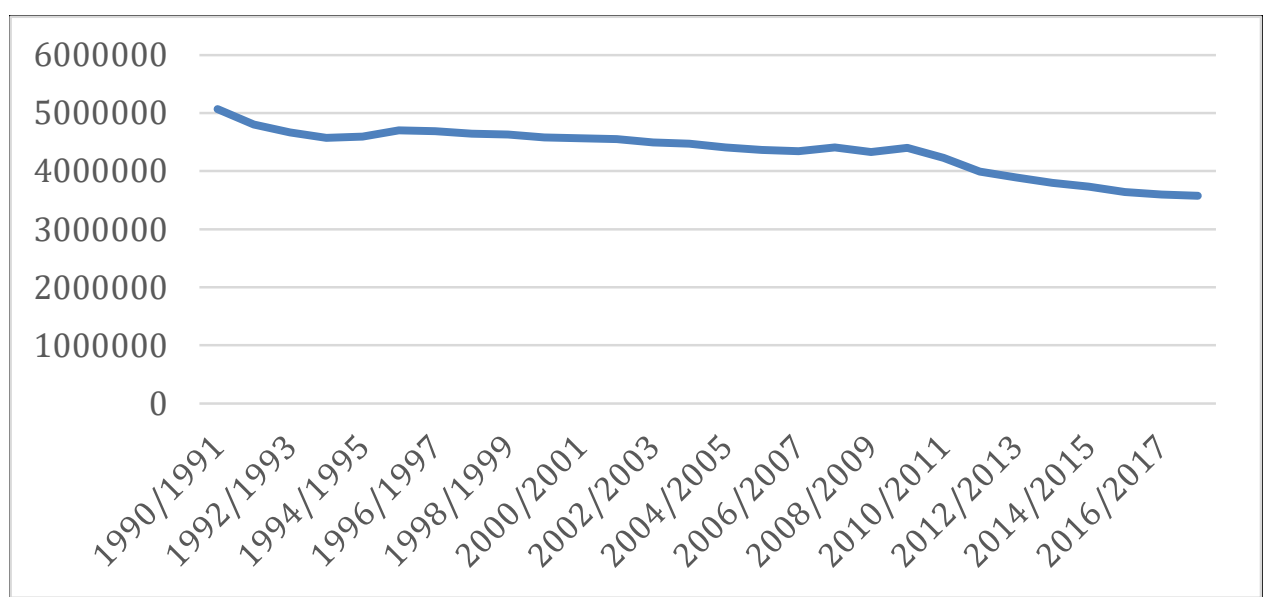

Figure 1. The evolution of the enrolled population between 1990/1991 and 2016/2017 Source: Annual Yearbook 2018, National Institute of Statistics 
Figure 1 is important to highlight the dramatic decrease of the school population due to the drastic decrease in the birth rate in Romania.

From figure 2 we can conclude that the number of pupils between 1990 and 2016 decreases from 4.121 .080 persons in $1990 / 1991$ to 2.497 .768 pupils in $2016 / 2017$. The decline of the total number of pupils are motivated by the decrease of the number of total population.

The average of the total number of pupils was 3.159 .015 persons in the period 19902016.

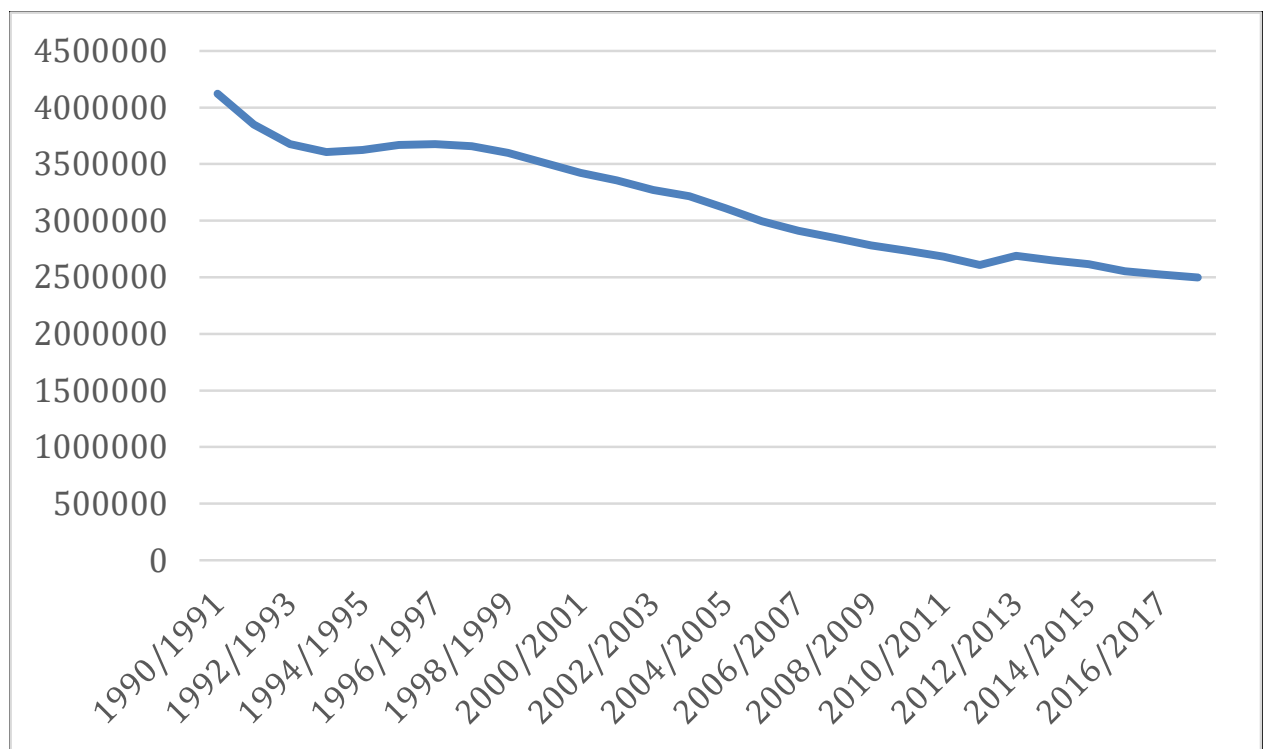

Figure 2. The evolution of number of pupils between 1990/1991 and 2016/2017

Source: Annual Yearbook 2018, National Institute of Statistics

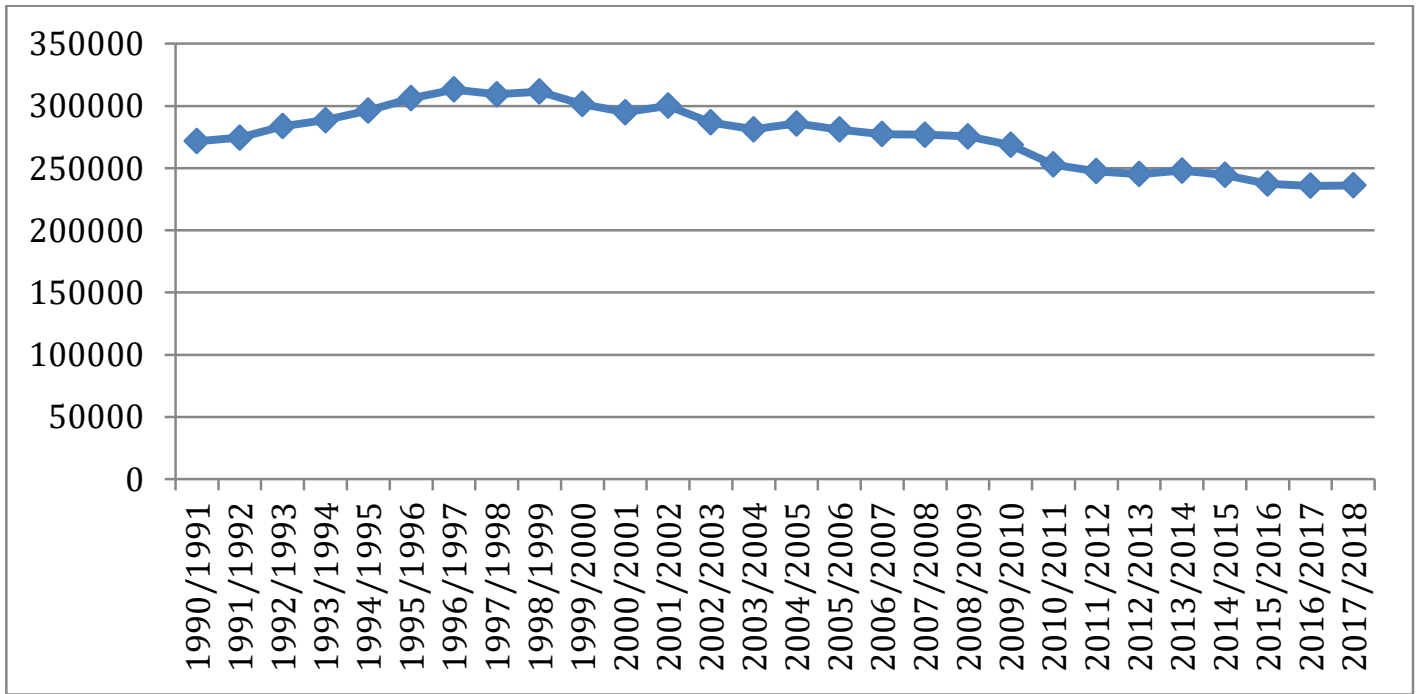

Figure 3. The evolution of number of teachers between 1990/1991 and 2016/2017

Source: Annual Yearbook 2018, National Institute of Statistics

From figure 1, it turns out that during the period 1990-2018, the number of the teaching staff registered a descendent trend. It decreases from 271.719 persons in 1990 to 
236.208 persons in 2016.

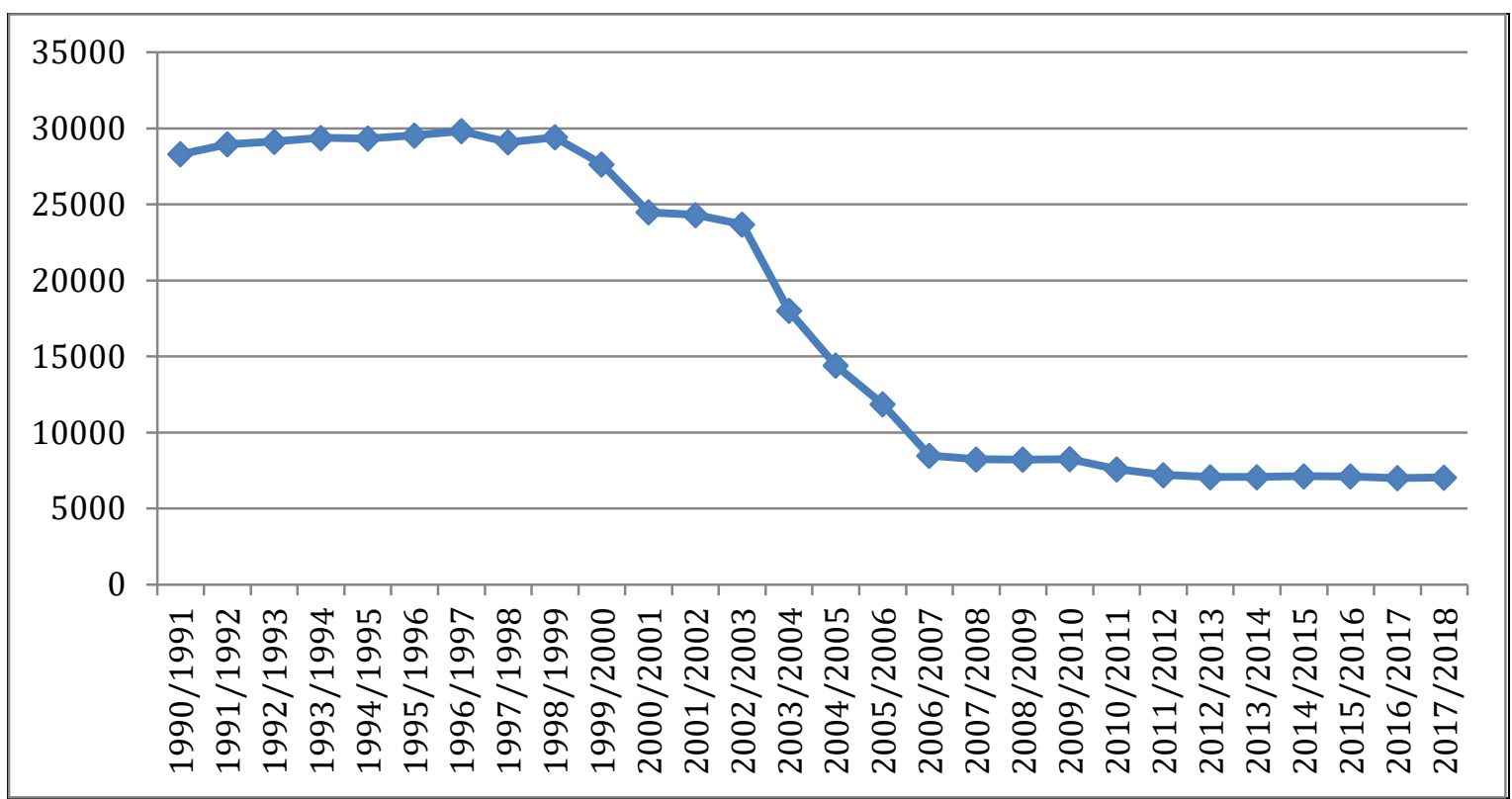

Figure 4. The evolution of number of schools between 1990/1991 and 2016/2017

Source: Annual Yearbook 2018, National Institute of Statistics

From figure 3 we can conclude that in the analyzed period the number of schools decreases from 28.303 schools in 1990/1991 to 7.047 schools in 2017/2018. The average of schools in the period 1990-2018 was 17.775 schools. The number of schools decrease from year to year with 787 schools.

\section{Results and discussions}

We considered as dependent variable number of teachers and the independent variables as number of schools and enrolled population. The analyzed period was 1990 and 2017.

Table 1. The equation of the multiple regression model

\begin{tabular}{ccccc} 
& Coefficient & Std. Error & t-Statistic & Prob. \\
\hline \hline Intercept & 122429.2 & 40910.11 & 2.992640 & 0.0061 \\
Enrolled population & -0.031424 & 0.010768 & -2.918328 & 0.0073 \\
Schools & -0.962694 & 0.425214 & -2.264020 & 0.0325 \\
\hline \hline Mean dependent var & 0.000000 & S.D. dependent var & 0.000000 \\
S.E. of regression & 12645.71 & Akaike info criterion & 21.82898 \\
Sum squared resid & $4.00 \mathrm{E}+09$ & Schwarz criterion & 21.97172 \\
Log likelihood & -302.6057 & Hannan-Quinn criter. & 21.87262 \\
Durbin-Watson stat & 0.263848 & & \\
\hline \hline
\end{tabular}

Source: Authors' own research 


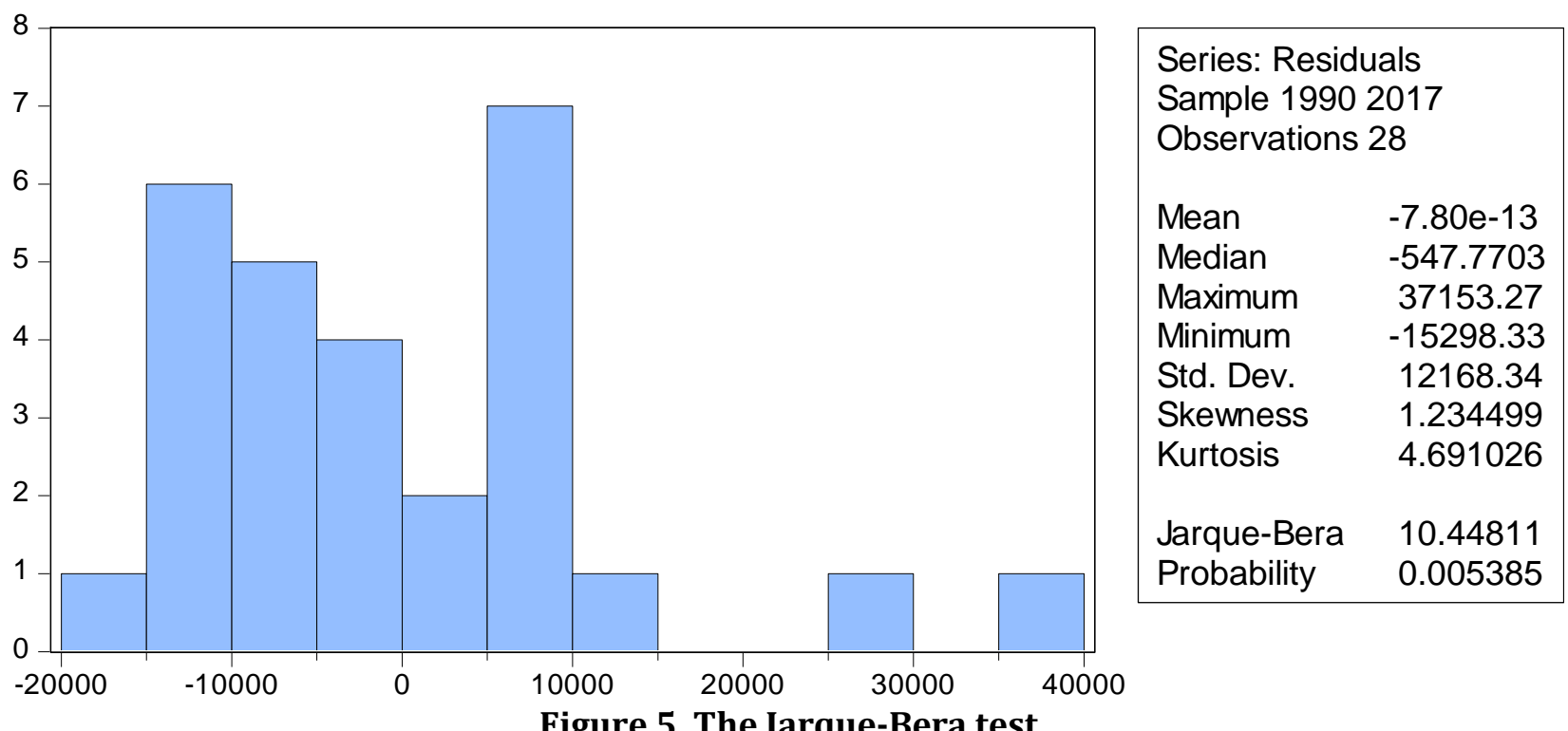

Table 2. The results for White test

Heteroskedasticity Test: White

\begin{tabular}{|c|c|c|c|c|}
\hline $\begin{array}{l}\text { F-statistic } \\
\text { Obs*R-squared } \\
\text { Scaled explained SS }\end{array}$ & $\begin{array}{l}61.45871 \\
26.12933 \\
38.44229\end{array}$ & $\begin{array}{l}\text { Prob. } F(5,22) \\
\text { Prob. Chi-Squ } \\
\text { Prob. Chi-Squ }\end{array}$ & $\begin{array}{l} \\
e(5) \\
\text { e(5) }\end{array}$ & \\
\hline Variable & Coefficient & Std. Error & t-Statistic & Prob. \\
\hline $\begin{array}{c}\text { C } \\
(-1)^{\star} \text { ENROLLED_POPULATIO } \\
(-1)^{\star} \text { SCHOOLS } \\
\text { ENROLLED_POPULATIO^2 } \\
\text { ENROLLED_POPULATIO*SCHOOLS } \\
\text { SCHOOLS^2 }\end{array}$ & $\begin{array}{r}5.23 \mathrm{E}+09 \\
1729.487 \\
484967.5 \\
0.000119 \\
0.117858 \\
-1.678990\end{array}$ & $\begin{array}{l}5.30 \mathrm{E}+09 \\
2889.041 \\
124179.8 \\
0.000389 \\
0.031463 \\
0.644122\end{array}$ & $\begin{array}{r}0.985785 \\
0.598637 \\
3.905366 \\
0.306686 \\
3.745946 \\
-2.606635\end{array}$ & $\begin{array}{l}0.156854 \\
0.125432 \\
0.023985 \\
0.097851 \\
0.039811 \\
0.017894\end{array}$ \\
\hline $\begin{array}{l}\text { R-squared } \\
\text { Adjusted R-squared } \\
\text { S.E. of regression } \\
\text { Sum squared resid } \\
\text { Log likelihood }\end{array}$ & $\begin{array}{r}0.933190 \\
0.918006 \\
79988794 \\
1.41 \mathrm{E}+17 \\
-545.8811\end{array}$ & \multicolumn{3}{|c|}{$\begin{array}{l}\text { Mean dependent var } \\
\text { S.D. dependent var } \\
\text { Akaike info criterion } \\
\text { Schwarz criterion } \\
\text { Hannan-Quinn criter. }\end{array}$} \\
\hline
\end{tabular}

Source: Authors' own research

From table 1 we can conclude that the coefficient of the enrolled population is -0.03 , which means that if enrolled population increases with one person, the number of teachers decreases with 0.03 persons while the number of schools is constant.

The coefficient of the number of schools is -0.96 which means that if the number of schools increases with one school, the number of teachers decreases with 0.96 persons in the condition that enrolled population is constant.

The coefficients are significant statistically and the multiple regression model is valid. 
The Durbin-Watson test value is 0.26 . The model presents positive autocorrelation and it can be improved by adding another factor of influence: motivating salary, professional fulfillment.

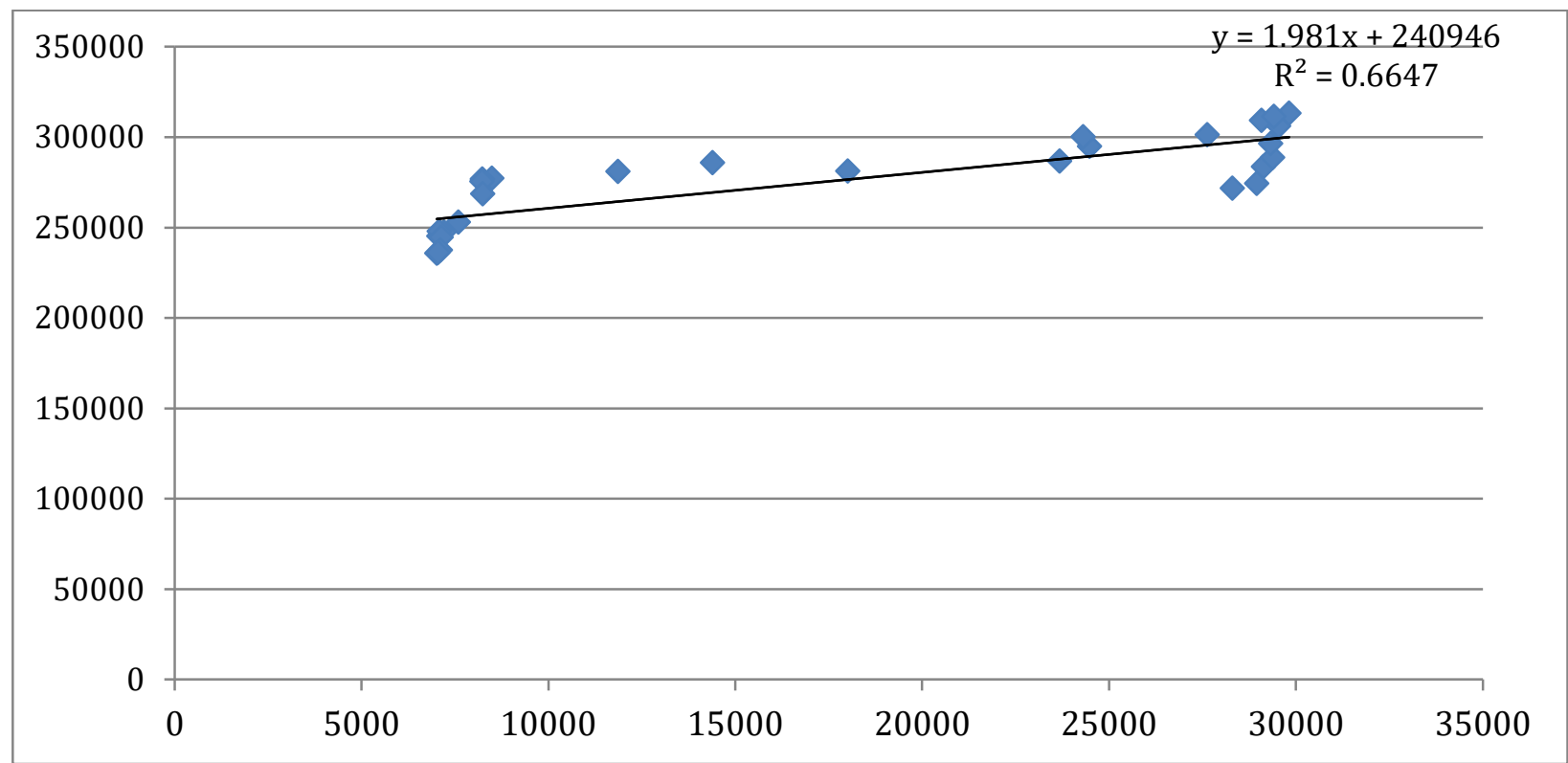

Figure 6. The dependence between number of schools and number of teachers

From figure 6, we can conclude that if number of schools increases with one school, the number of teachers will increase with 1.981 person.

From figure 7, we can conclude that if the enrolled population increase with one person, the number of teachers will increase with 0.0514 persons.

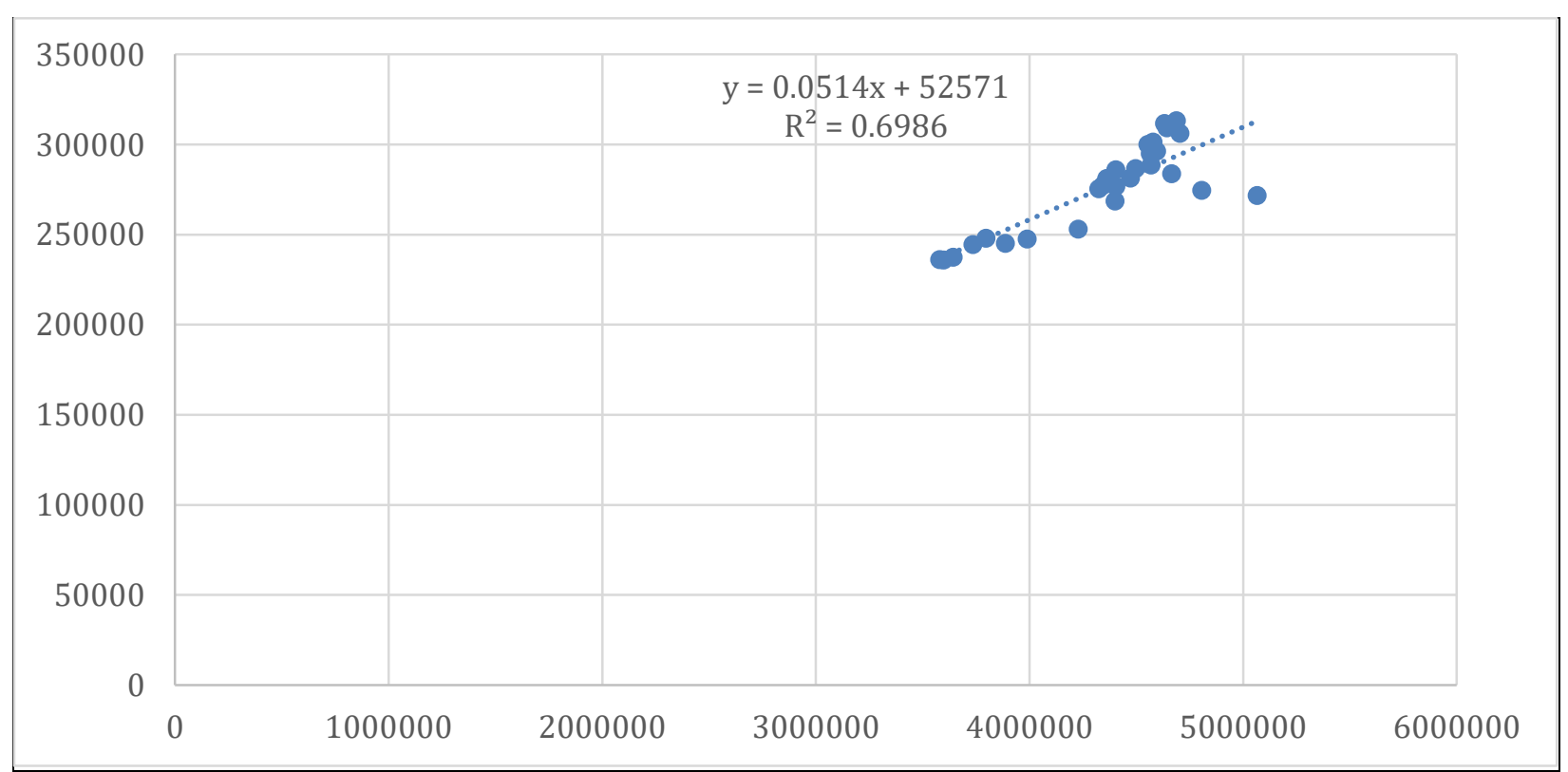

Figure 7. The dependence between enrolled population and number of teachers 


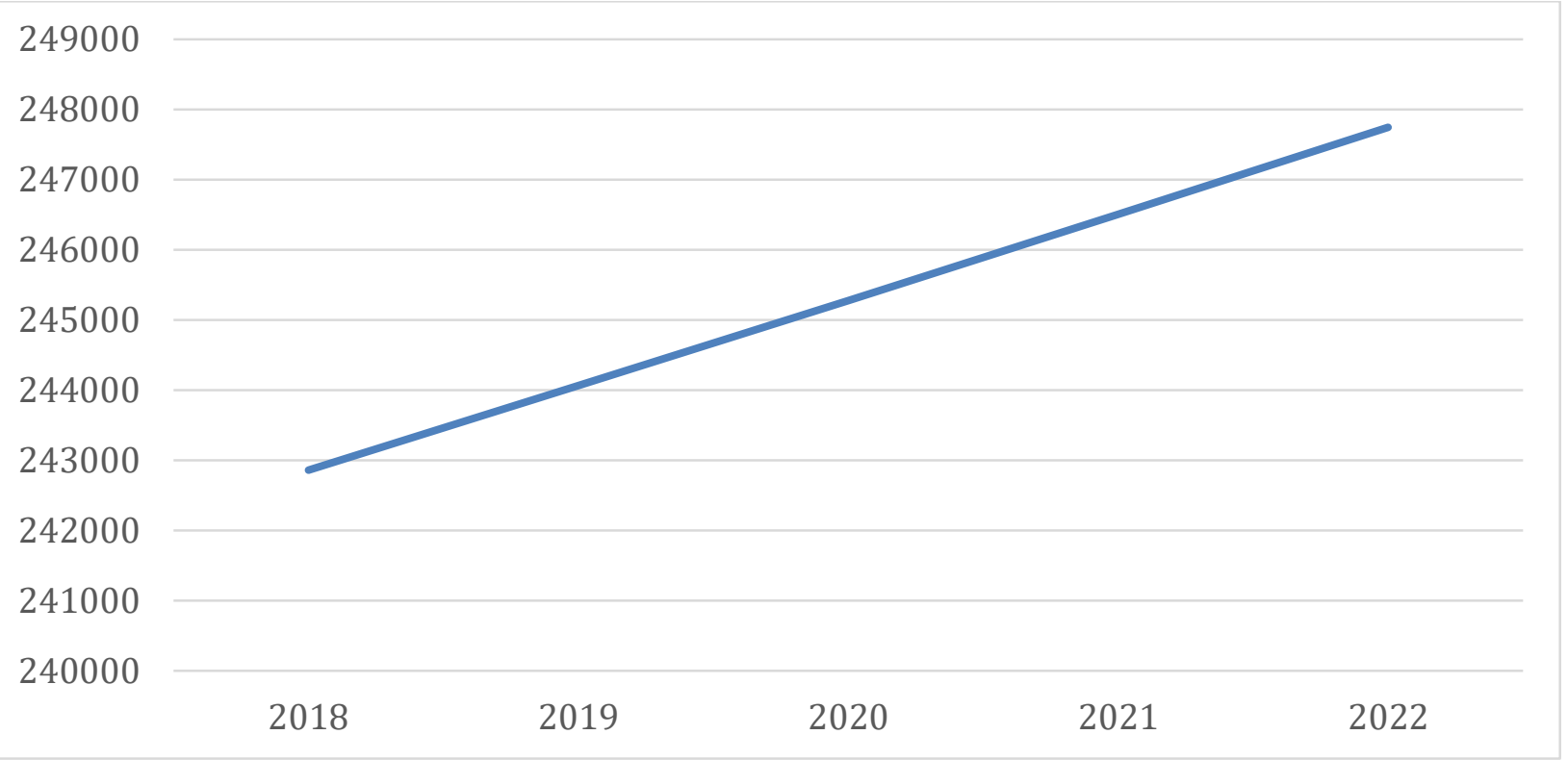

Figure 8. The prognosis of the number of teachers between 2018 and 2022

The prognosis until 2022 related an increase of the number of teachers.

\section{Conclusion}

An important problem of the people from all over the world is the future forecasts of employment which has become increasingly difficult due to the increase of the share of the economically inactive population, of the accentuation of the demographic aging process, of the tendency of accentuated rate increase. unemployment, but also due to the global economic crisis, under the conditions of sustainable economic development and the emergence of the new knowledge economy. In these conditions, the equalization of the demand with the job offer is increasingly difficult, both qualitatively and quantitatively. It is very difficult for companies to achieve a good adequacy of the qualifications of the employees with the requirements of the jobs they occupy in companies. For most countries of the world, it is very important to apply quantitative methods and models to determine the labor force needs, both on educational levels and on branches of the national economy. It is a major aspect for the best functioning of the national economy to quantify the deficit / surplus of labor force for the elaboration of the future education plans, but also for the employment on the jobs in the economy of future employees who are better prepared for the respective job. It also plays a very important role, and the learning process continues by the fact that the employee can complete his knowledge even though he is employed in the respective branch of activity, in order to be informed with the latest scientific discoveries in the respective field. It is necessary to know the dynamics of the demand, respectively of the supply of labor force, by groups of occupations, by qualification levels, and by branches of activity respectively. Employment forecasts are needed for both jobseekers, politicians who make decisions in the educational and educational areas, and last but not least, for economic analysts. These projections are especially needed at this time when the world is facing the economic crisis, with rising unemployment rates in the EU Member States and in the accession states of Eastern Europe. 


\section{References}

Hughes, G.(1991). Manpower Forecasting:A Review of Methods \&Practice in Some OECD Countries.

Dublin: Economic and Social Research Institute, Report No. 1 FAS/ESRI Manpower Studies.7481.

Dogaru I. (2002).Formula de finanţare a învăţământului preuniversitar din România: studii şi proiecte,, Bucharest,Economic Publishing House.

Noguera, F., Khouatra, D,. (2004) .Gestion des ressources humaines et création de valeur organisationnelle: concept set outils de mesure.

Congres Association francophone de Gestion des Ressources Humaines, Montréal, Canada.

Smith, M. K. (2001) .Peter Senge and the learning organization,

The encyclopedia of informal education,45-56.

Venkatraman, N., Subramaniam, M.,(2002). Theorizing the future of strategy: Questions for shaping strategy research in the knowledge economy

The Handbook of Strategy and Management, Sage Publications.

Visco I. (2001). Ageing Population Economic Issues and Policy Challenges

Conference OECD "Economic Policy for Ageing Societies", Paris, OECD, 4-10. 